Case Report

\title{
A RARE CAUSE OF URETHRAL OBSTRUCTION IN AN INFANT - CONGENITAL POSTERIOR URETHRAL POLYP
}

\author{
Sandeep B. Rai ${ }^{1} \&$ Raghu Shankar ${ }^{2}$ \\ ${ }^{1}$ Professor \& HOD, ${ }^{2}$ Associate Professor, Department of Pediatric Surgery \\ K.S. Hegde M edical Academy, Nitte University, Deralakatte, M angalore - 575 018, Karnataka India. \\ Correspondence \\ Raghu Shankar \\ Associate Professor, Department of Pediatric Surgery, K.S.Hegde M edical Academy, Nitte University, Deralakatte, \\ M angalore - 575 018, Karnataka, India. \\ Ph. : +918242204471 E-mail : drraghubhat@yahoo.com
}

\begin{abstract}
:
Urethral polyp is a rare finding in young children. These are congenital fibroepithelial benign polyp in the prostatic urethra. They present with acute or intermittent urinary obstruction, hematuria or voiding dysfunction. Their diagnosis requires a high index of suspicion because of variability in presentation. Diagnosis can be made by ultrasonography or micturating cystourethrogram, however cystourethroscopy is confirmatory. Transurethral resection is possible in almost all the cases and recurrence is almost unknown. We report a case of this rare lesion in a male infant with a severe phimosis.
\end{abstract}

Keywords : urethral polyp; urethral obstruction; severe phimosis.

\section{Introduction:}

Congenital urethral polyps are rare benign lesions usually presenting in the first decade of life. They usually present with acute or intermittent urinary retention. However, they can also present with hematuria, voiding dysfunction, or infection. It is predominantly seen in males and has been reported only in a couple of girls. They are situated in the prostatic urethra arising from the veru montanum. Diagnosis is made by micturating cystourethrogram or cystoscopy. Herein we report a rare case of urethral polyp in a one year old child. We would like to highlight the need for evaluating even a single minor episode of urinary obstruction and not just consider presence of phimosis as a cause for such episode.

\section{Case report:}

A 1 year old male child was referred for evaluation of an episode of urinary retention which had occurred a week

\begin{tabular}{|c|}
\hline Access this article online \\
\hline Quick Response Code \\
\hline
\end{tabular}

prior. Child had been brought to the emergency with acute retention of urine. The child had voided on his own in the emergency by encouraging him to do so and had not required a catheterization. No similar episode had occurred earlier. On enquiry, mother gave a history of poor stream of urine noticed occasionally. On examination, the child had phimosis and ballooning of prepuce while voiding without any evidence of balanoposthitis. The urine examination and culture were not suggestive of urinary tract infection (UTI). Ultrasonography (USG) of the kidney, ureter and bladder (KUB) did not reveal any abnormality. Child underwent a circumcision and cystourethroscopy. A pedunculated urethral polyp was seen arising from the proximal end of the veru montanum (fig.1) and was prolapsing into bladder neck. Transurethral fulguration at the base of the polyp and piecemeal excision was done. A check cystoscopy done a month later revealed no residual lesion and a normal veru montanum. Patient is asymptomatic and stream has improved as per mother's observation.

\section{Discussion:}

Posterior urethral polyps are uncommon lesions almost exclusively of the male urethra. Only a couple of case report in the literature describes it in the females. ${ }^{1}$ it has been seen in pediatric and adult patients from newborn to 70 years of age., ${ }^{2,3}$ Those diagnosed in the pediatric age group are congenital polyps which almost always arise 


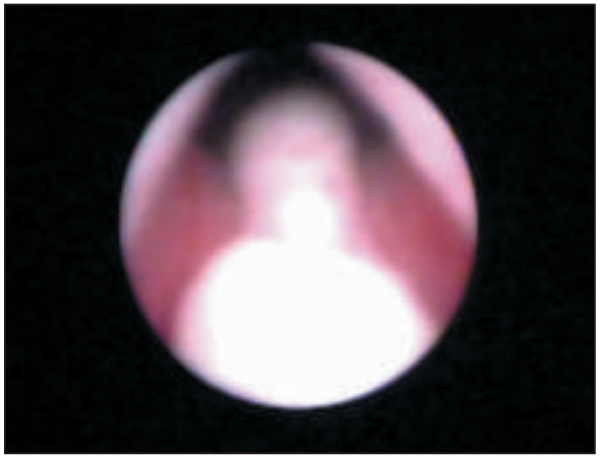

Fig 1. : urethral polyp arising from the proximal end of veru montanum.

from the veru montanum. ${ }^{4}$ They are benign fibro-epithelial polyps. The main presenting symptoms in children is with acute retention or intermittent obstruction due to prolapse into bladder or urethral obstruction. ${ }^{4}$ Other symptoms can be hematuria, urinary tract infection, post void dribbling, enueresis. ${ }^{3,5}$ Differential diagnosis of urine retention would include urethral valves, stones, severe phimosis with or without balanoposthitis, ureteroceles, bladder neck region diverticula, constipation with fecal mass compressing the bladder neck and tumors like urothelial papilloma or rhabdomyosarcoma. Associated vesicoureteral reflux has been noted in some reports. ${ }^{5,6}$ Unlike posterior urethral valves, polyps do not damage the urinary tract. ${ }^{7}$

Ultrasonography and micturating cystourethrogram (M CU) are used routinely for evaluation of the lower urinary tract symptoms in children. These can diagnose a polyp as a filling defect in the posterior urethra. However, cystourethroscopy is confirmatory. We did not get a M CU done in this case. Since the USG had revealed no KUB abnormality and, our patient had to undergo a circumcision for phimosis, we opted for cystourethroscopy during the same anaesthesia.

Transurethral resection by electrocautery, cold knife, laser are the treatment options. ${ }^{5,6}$ Open surgery should be used only when transurethral resection is not possible. The prognosis of the posterior urethral polyp is excellent without any recurrences after complete resection. Following electrocautery resection we did not get tissue for the histopathological examination as the cauterised polyp was retrieved in small bits.

\section{Conclusion:}

Posterior urethral polyps are rare obstructive lesions mainly of the male urethra. Presence of phimosis in a child who presents with even a minor episode of urinary obstruction should not hold one back from appropriate evaluation. Urethral polyp should be considered in the differential diagnosis of urethral obstruction in a male child .Transurethral resection offers excellent prognosis.

\section{References:}

1. Demircan M, Ceran C, Karaman A, Uguralp S, M izrak B. Urethral polyps in children: a review of the literature and report of two cases. Int J Urol. 2006;13:841-3.

2. Tsuang W, Rapp DE, Feinstein KA, Orvieto M A, Close CE. Urethral polyp in asymptomatic male infant with prenatal hydronephrosis. Urology 2006;67:1085e9-e11.

3. Tsuzuki T, Epstein JI. Fibroepithelial polyp of the lower urinary tract in adults. Am J Surg Pathol 2005;29:460-6.

4. Jain P, Shah H, Parelkar SV, Borwankar SS. Posterior urethral polyps and review of literature. Indian J Urol 2007;23:206-7.

5. De Castro R, Campobasso P, Belloli G, Pavanello P. Solitary polyp of the posterior urethra in children: Report on seven cases. EurJ Pediatr Surg 1993;3:92-6.

6. Eziyi AK, Helmy TE, Sarhan OM , Eissa WM , Ghaly M A. M anagement of male urethral polyps in children: Experience with four cases. Afr J Paediatr Surg 2009;6:49-51

7. Casale AJ. Posterior urethral valves and other urethral anomalies. Wein AJ, Kavoussi LR, Novick AC, Partin AW, Peters CA, editors. Campbell'surology. Vol. 49th ed. W.B. Saunders; 2007. p. 3583-603

8. Gleason PE, Kramer SE. Genitourinary polyps in children. Urology 1994;44:106-109. 